\title{
Pathogenesis of Hyperthyroidism
}

\author{
Kiyoshi MIYAI, M. FUKUCHI, N. AMINO \\ and M. AZUKIZAWA \\ Department of Medicine, Osaka University Medical School, Osaka, Japan
}

I. TSH secretion in patients with Graves' disease

1. In hyperthyroid patients, serum TSH levels determined by radioimmunoassay were undetectable $(<1.0 \mu \mathrm{U} / \mathrm{ml})$.

2. Three euthyroid patients with Graves' disease were treated with 1-methyl-2mercaptoimidazole followed by thyroxine. Reciprocal changes in TSH and thyroxine levels were observed, but LATS did not change.

II. LATS in Graves' disease

1. Concentration and identification of LATS: LATS cantaining IgG which was separated from serum by DEAE-Sephadex column chromatography was passed through a GM-G column, and LATS fractions with high specific activity were obtained. The protein in these fractions with LATS was identified by immunoelectrophoresis as IgG.

There was no correlation between LATS activity and the concentrations of IgG, IgA and IgM which were measured by immunodiffusion technique.

2. LATS production by lymphocyte culture: Peripheral lymphocytes obtained from patients with Graves' disease were cultured with phytohemagglutinin, and LATS like activity was detected in the cultured medium. The LATS like activity was identified as LATS, by the time- and dose-response curves, association with IgG fraction of DEAESephadex column chromatography, and neutralization with anti-IgG serum. Neither LATS nor TSH like activity was detected in the control cultured media.

3. The nature of LATS inhibitor in thyroid gland: LATS inhibitor was investigated in an attempt to find a specific antigen to LATS.

1) Incubation of LATS-IgG with human thyroid homogenates resulted in inhibition of LATS activity. When the subcellular fractions were used, LATS-inhibitory activity was demonstrated in microsomal fraction and cell sap, and dose-response relationship was obtained.

2) Following treatment with acidic buffer ( $\mathrm{pH} 3.0$ ) or $2 \mathrm{M}$ NaSCN where dissociation of antigen antibody complexes is known to occur, some of the LATS activity was recovered from microsomes which were previously incubated with LATS-IgG. Similar results were obtained when the mixture of the LATS-IgG and thyroid cell sap was treated with acidic buffer.

3) By incubation with thyroid cell sap, LATS activity was inhibited but TSH was not.

4) The LATS inhibitory activity of the cell sap was markedly reduced when the cell Vol. 45 No. 10 
sap was pretreated with acidic buffer $(\mathrm{pH} 2.5,3.0), 2 \mathrm{M}$ NaSCN or $6 \mathrm{M}$ urea.

5) The thyroid cell sap was fractionated by means of gel filtration using Sepharose $4 \mathrm{~B}$, but the LATS inhibitory activity was distributed to each fraction. When the cell sap was applied to a column of DEAE-cellulose, the LATS inhibitory activity was concentrated in the fractions which were eluted by the buffer with high ionic strength.

4. Relationship between LATS and antithyroid antibodies:

1) No correlation was observed between LATS activity and titer of antithyroid antibodies which were determined by TRG for thyroglobulin, CFT and cytotoxic factor assay with thyroid microsomes.

2) A case of "Graves' disease without hyperthyroidism" was presented. The patient has exophthalmos, goiter, LATS and antithyroid antibodies. Histological examination of thyroid gland revealed the findings of chronic thyroiditis.

5. No effect of LATS was found on adenyl cyclase activity which was determined by the method of Pastan but the further experiments are necessary to confirm the finding.

(See pp. 1004 1015) 


\section{シンポジゥム II 甲状腺研究の進歩}

\section{B 臨 床 的研 究}

\section{甲状腺機能光進症の病態生理}

阪大第 1 内科

宮 井 潔, 福地 稔
網 野 信 行, 小豆沢瑞夫

\section{I 緒言}

甲状腺機能穴進症の病態生理に関しては, 従来から各方面で研究がすすめられて来たが，なお未解決な問 題が多く，特にその病因については明らかにされていない，従つて病態生理の解明にあたつては，まずその 病因を追求するととが重要な課題となつている.

さて甲状腺機能亢進症状を来たす疾患としては，いわゆるバセドウ病のほか，甲状腺ホルモンを過剩に分 泌する腫瘍 (Plummer 病), 特殊例として TSH 過剩分泌を伴う下垂体腫瘍1), 甲状腺ホルモン結合蛋白異 常による代謝元進症例2，3)などが報告されている。しかし機能六進症のうち最も多くをを占めるバセドウ病 の病因については，本症か記載されてから一世紀余りを経た今日においてもなお明らかにされていない，本 症の病因に関連する因子としては, TSH, LATS 始め, Exophthalmos producing substance (EPS) ${ }^{4}$, , バ セドウ病下垂体異常甲状腺刺激物質 ${ }^{5}$ などのほか，その背後にある遺伝的支配など多くのものがあげられる が，ここでは甲状腺機能に直接関与し，しかも最近特に注目されている TSH と LATS の問題につき我々 の成績を中心に述べる.

\section{II バセドウ病における TSH}

\section{1. 血中 TSH}

本症患者血中又は尿中 TSH b bioassay で測定した従来の成績から推定すると，TSH の過剩分泌説は 否定的であるが, bioassay の感度の点から確定的な結論を得るととは因難であつた，我々はての点を明らか にするため，精度・感度のすぐれた radioimmunoassay を用い本症患者血中の TSH を測定した。方法は ethanol saline 法 $^{6}$ 又は二抗体法 ${ }^{7)}$ 亿準じ，精製人 TSH $\left({ }^{131}\right.$ I 又は ${ }^{125}$ I 標識用）と抗精製人 TSH 鬼血清 (N.P.A.より提供) を用い，Human Thyrotrophin Research Standard A. (NIMR) を標準として測定 した.

未治療バセドウ病患者 11 例の血中 TSH を測定した結果は，いずれも測定感度 $(1.0 \mu \mathrm{U} / \mathrm{ml})$ 以下であり， 正常值（<1.0〜2.5 $\mu \mathrm{U} / \mathrm{ml})$ 亿比しむしろ低值の傾向を示した. 同様な成績は Odell ら れており，本症における機能圥進症状の原因として TSH 過剩説は否定的である.

\section{Feed back relation}

健常人における TSH 分泌が血中甲状腺ホルモンレベルの変動によつて調節されているととは feed back relation として周知の事実であるが，本症における TSH 分泌についてはなお問題が多い，そてで治療後 euthyroid 下限にあり LATS を有するバセドウ病患者 3 例に，抗甲状腺剤 1-methyl-2-mercaptoimidazole $30 \mathrm{mg} /$ 日, 経口) 次いで甲状腺ホルモン（thyroxine $\mathrm{T}_{4} 2 \mathrm{mg}$ 筋注）を投与し, 血中 TSH を radio-im- 
munoassay で, 又 $\mathrm{T}_{4}$ を competivive protein binding analysis (Tetrasorb) で経時的に測定した。 その結果はFig. 1 亿示す通り，血中 $\mathrm{T}_{4}$ の減少，増加，飞伴ない， $\mathrm{TSH}$ の增減が認められた。 ${ }^{8)}$ この成績 は, 本症においても TSH の feed back relation が保たれているてとを示すものである. なおこの間同時 に測定した LATS が殆んど変化を示さなかつたととは，本症において，血中甲状腺ホルモンレベルが高い そも拘らず甲状腺機能が抑制されないという事実と考え合わせ興味深い.

Fig. 1. Plasma TSH levels during antithyroid drug administration in patients with Graves' disease with LATS in euthyroid state
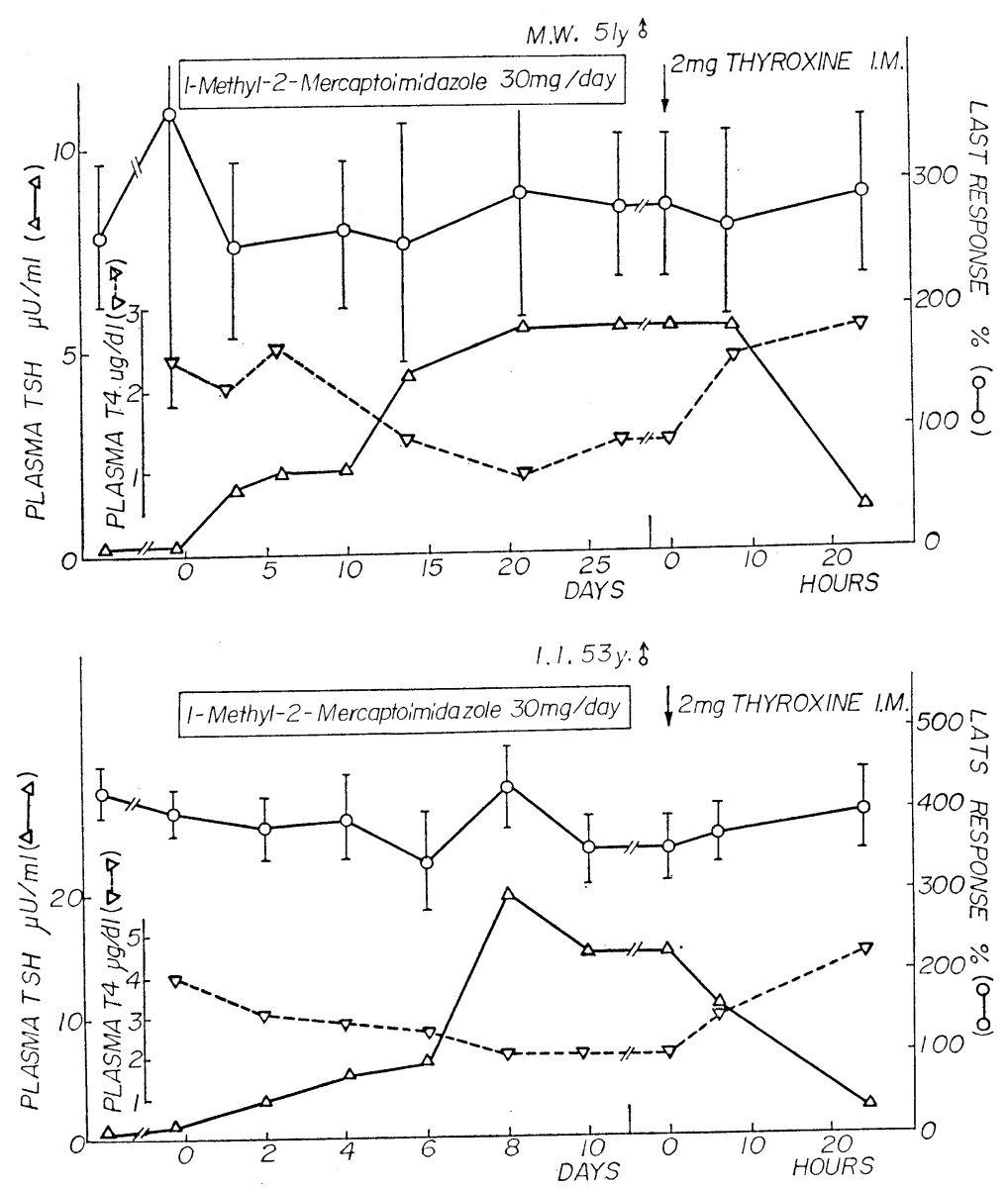

III LATS に関する研究

1956年 Adams ${ }^{9}$ によつてバセドウ病患者血中から見出された甲状腺刺激物質 Long-acting Thyroid Stimulator (LATS) は, 種々な点で TSH とは異なり, 本症の病態と密接な関係ががあるものとして注目さ れている.

1. LATS の分離・同定

1964年 Kriss ${ }^{10)}$ は LATS が IgG 分画にあり且つ抗 IgG 血清で中和されることから LATS 抗体説を 提唱した。著者ら ${ }^{11)}$ は LATS 含有血清を DEAE-Sephadex column chromatography で分離した所, 
Fig. 2. Separation of fraction D I of DEAE-Sephadex by CM-cellulose column chromatography.

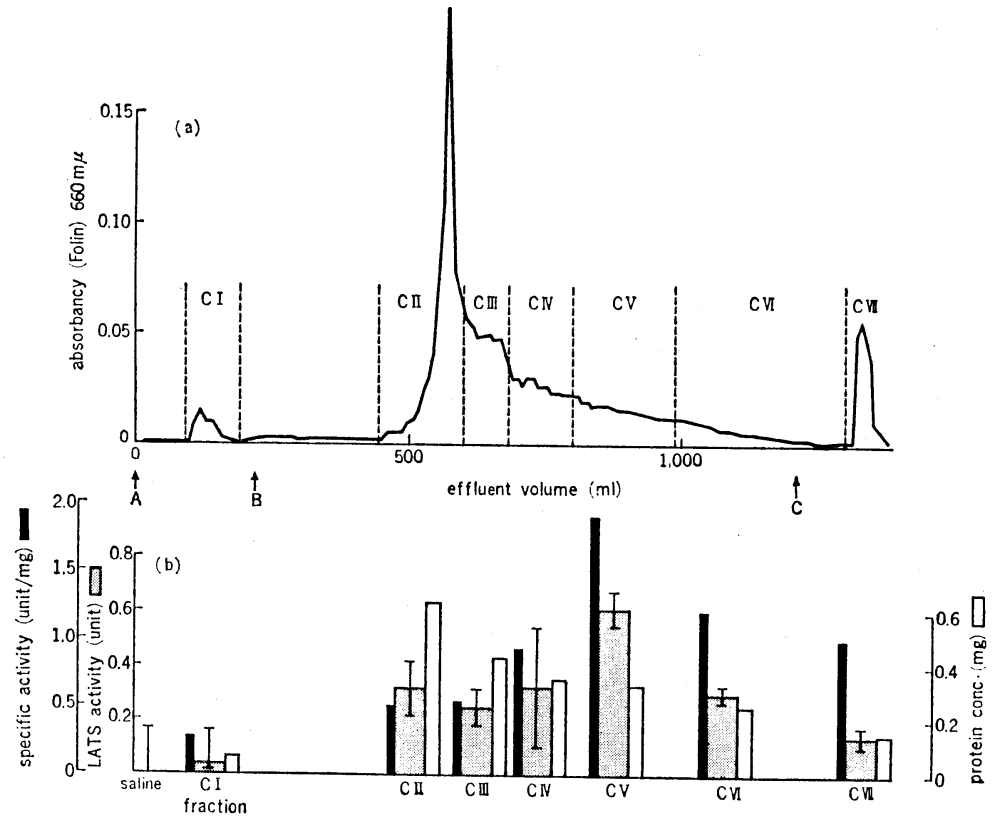

LATS 活性は未吸着の第 1 分画にあり，更にこれを CM-C column chromatography を用いてイオン強度 を gradient に変化させて分画すると. Fig. 2 の如く活性と蛋白濃度の間に解離がみられ，蛋白量当 LATS 活性が原血清の 30-40 倍有する分画が得られた。これら LATS 含有分画は免疫電気泳動上 pure IgGで あるととを証明した。また LATS 活性は抗 $\operatorname{lgG}$ 血清で中和されるが，抗 IgA，抗 IgM では中和されな いととを確めた。

以上の成績は，LATS が IgG と associate しているととを示す.ただ免疫拡散法で測定した本症患者血 清の IgG, IgA, IgM 濃度が，LATS 活性とは相関しないととから，LATS が IgG に含まれるとして も，その蛋白量は非常に少ないものと推定される.

Fig. 3. Time response curves in LATS assay of culture media, which were obtained when lymphocytes from patients with Graves' disease were cultivated with PHA (A) or without PHA (B) ; normal lymphocytes were cultivated with PHA (C) or without PHA (D) ; and media containing no cells were incubated with PHA (E) or without PHA(F).

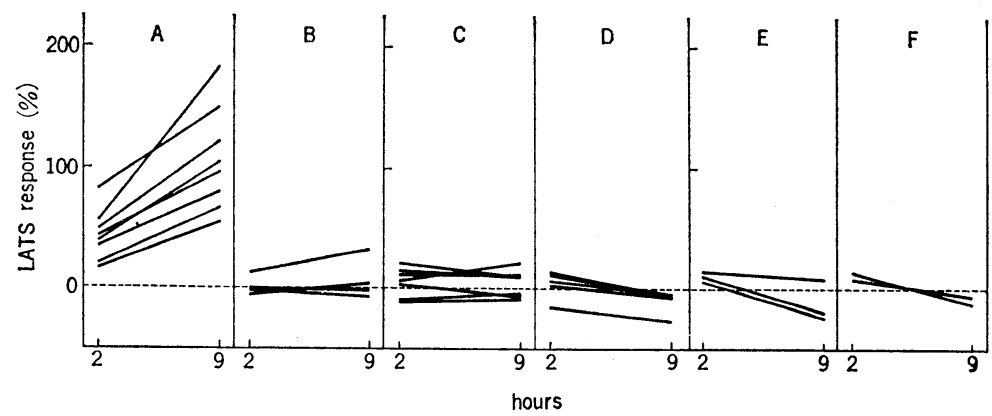




\section{2. リンパ球培養による LATS 産生 ${ }^{12)}$}

LATS が抗体産生細胞で産生され得るか否かを知るため, バセドウ病患者の未梢りンパ球を分離し, Phytohemagglutinin (PHA) を添加, $37^{\circ} \mathrm{C} 5$ 日間培養し, その培養液を濃縮, LATS 活性を測定した。 その 結果，リンパ球は blasttransformation を来し，Fig. 3 亿示すように，培養液中に LATS 様活性を認めた。 この活性は培養液を稀勫した際の時間反応曲線及ご用量反応曲線が血中 LATS と類似するてと, DEAESephadex column chromatography で IgG 分画にあり, 又抗 IgG 血清で中和されるととから LATS と同定した。な詨照実験，すなわち PHA 非添加バセドウ病リンパ球及び PHA 添加あるいは非添加健 常人リンパ球培養ではこのような活性は認められなかつた，免疫学の他の分野における PHA 添加リンパ球 培養実験の成績から考元，本実験は LATS が抗体産生細胞で産生され得るととを立証したものである.

Fig. 4. Neutralization of LATS activity by thyroid subcellular fractions

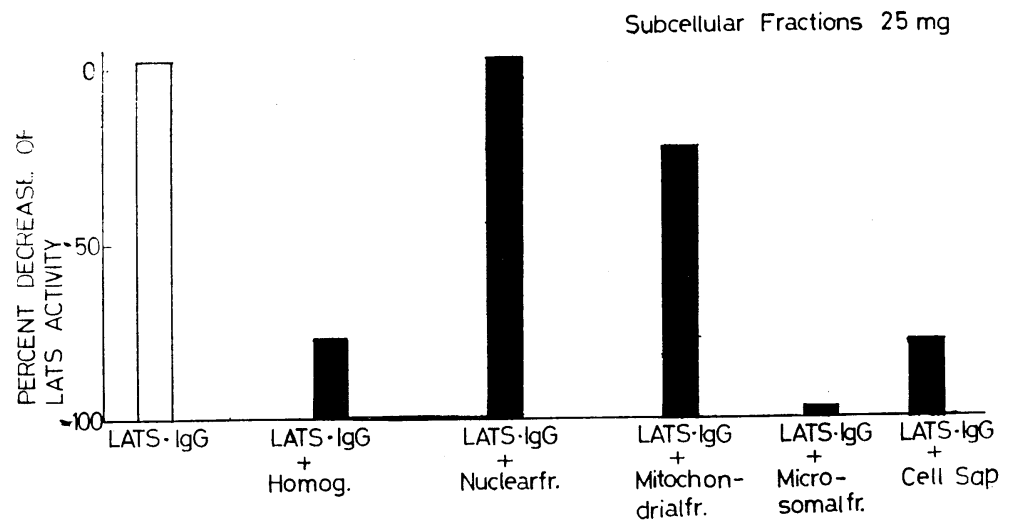

Fig. 5. Dose response relationship in neutralization of LATS by thyroid subcellular fractions
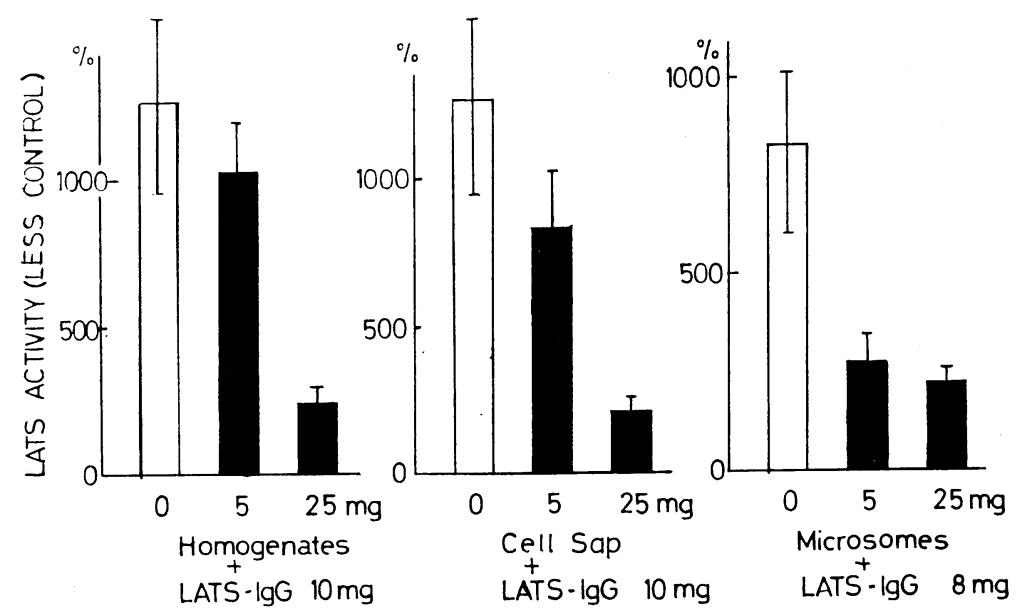
以上 LATS が IgG と associate するとと, 抗体産生細胞で産生されうるととのほか, 醅素, 還元剤に よる subunit の生成，副腎皮質ホルモン投与による诚少，LATS protector の成績なぞ LATS 抗体説を支 持する報告が多い。

\section{3. 甲状腺内 LATS 中和物質}

LATS に対する抗原を検索する方法として，従来，螢光物質又は放射性ヨード標識抗体法，感作法など 試みられているがなお問題が多い.

1966年 Beal ${ }^{13)}$ らは，甲状腺組織に LATS 活性を抑制する作用のあることを報告，以来抗原検索の一環 として諸家により研究がすすめられているが，その本体はまだ不明である。そてで著者らはての LATS 中 和物質について以下の如き実験を行なつた。

Fig. 6. Recovery of LATS by extraction with NaSCN from thyroid microsomes

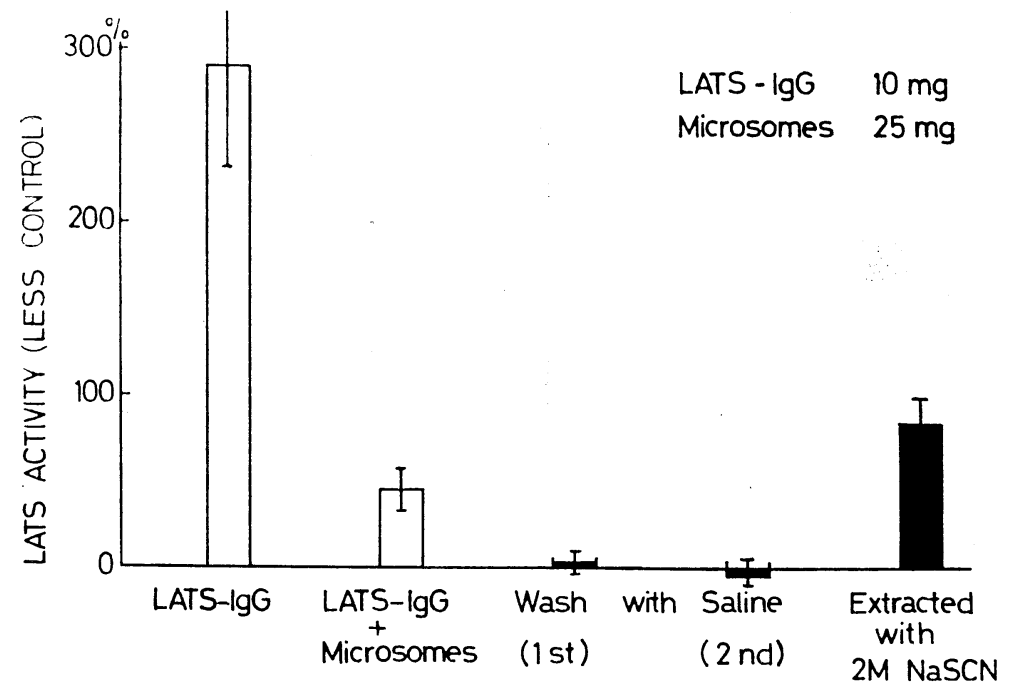

Fig. 7. Recovery of LATS by acid extraction of thyroid microsomes

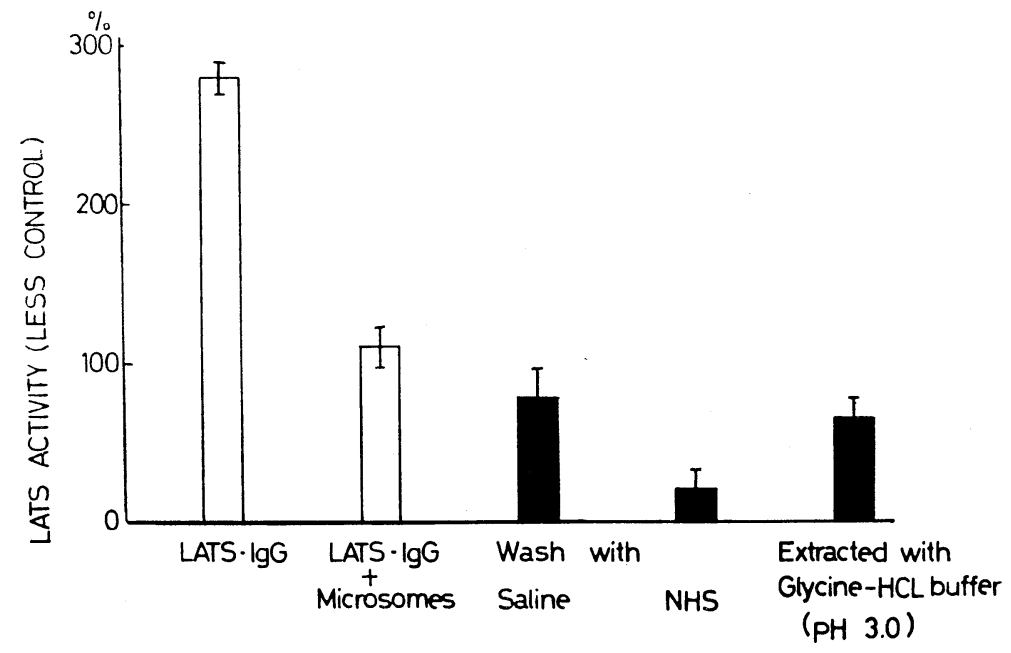


1) LATS-IgG に甲状腺 homogenate を添加, incubate 後, LATS 活性を測定すると, Fig. 4 の如く 対照に比して活性の抑制が認められた。 又 homogenate を超遠心で subcellular fraction に分画し, 各分 画を一定量づつ LATS-IgG に添加 incubate 後, cell sap 以外は再び超遠心し, その上清の LATS 活 性を測定すると，抑制能は microsomal fraction が最大で次いで cell sap にも認められた.

この際添加量と LATS 活性中和能との間にはFig. 5 亿示すように一定の用量反応関係が得られた.

2 ）甲状腺組織による LATS 活性中和作用が，抗原抗体反応に基ずくものか否かを検討する目的で以下 の実験を行なつた。すなわち，Fig. 6 亿示す如く, LATS-IgG と incubate した microsome を超遠心で 分離し，ての microsome を saline で洗條した場合には LATS 活性は殆んどみられなかつたが，更に抗

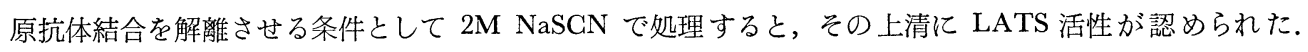

Fig. 8. Recovery of LATS by acid treatment of thyroid cell Sap

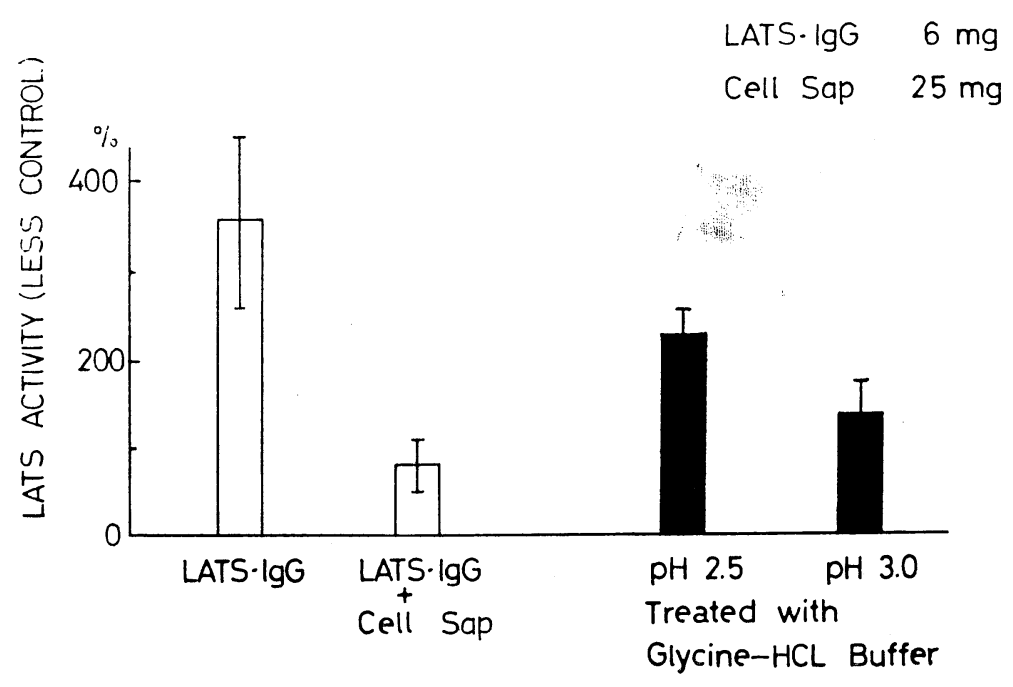

Fig. 9. Effect of thyroid cell Sap on LATS and TSH activity
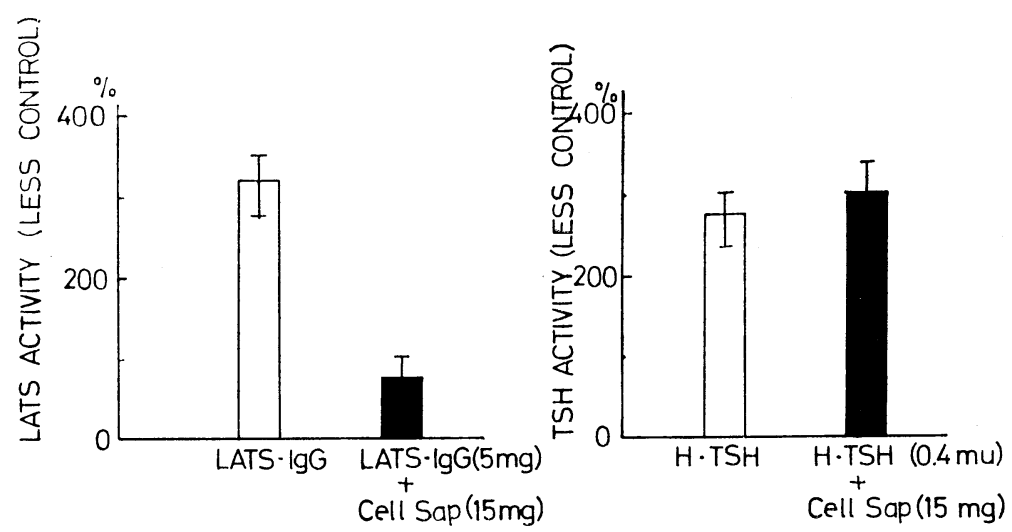
抗原抗体結合を解離させる他の条件として酸処理（glycine-HCl buffer pH 3.0）を行なつても略々同様の 結果が得られた(Fig. 7).

一方 cell sap そついての検討はFig. 8 亿示す通りである. LATS-IgG に cell sap を添加し, 酸処理をし ないで assay すると，先に述べたよにその LATS 活性は中和されるが， glycine-HCl buffer で pH2.5〜 3.0 とした後再び中性にした場合の LATS 活性は，酸処理をしないものより大であつた．

以上の成績は，甲状腺 microsom あるいは cell sap による LATS 活性中和が，非特異反応や，非可逆 的分解などによるものでなく抗原抗体反応によるものと考光ても予盾しないものである.

3 ）甲状腺 cell sap (15 mg) の添加により，LATS-IgG ( $5 \mathrm{mg})$ の活性は抑制されたが，人 TSH $(0.4$ mU) は抑制されなかつた。(Fig. 9)

4) 甲状腺 cell sap によるLATS 活性中和能の安定性を検討した。まず pH の影響についてば Fig. 10 の如く cell sap をpH 9.0 とし 2 時間後再び中性として LATS-IgG そ添加した場合には, 対照 $(\mathrm{pH} 7.4)$ と

Fig. 10. Effect of $\mathrm{pH}$ on LATS-neutralizing activity of thyroid cell sap

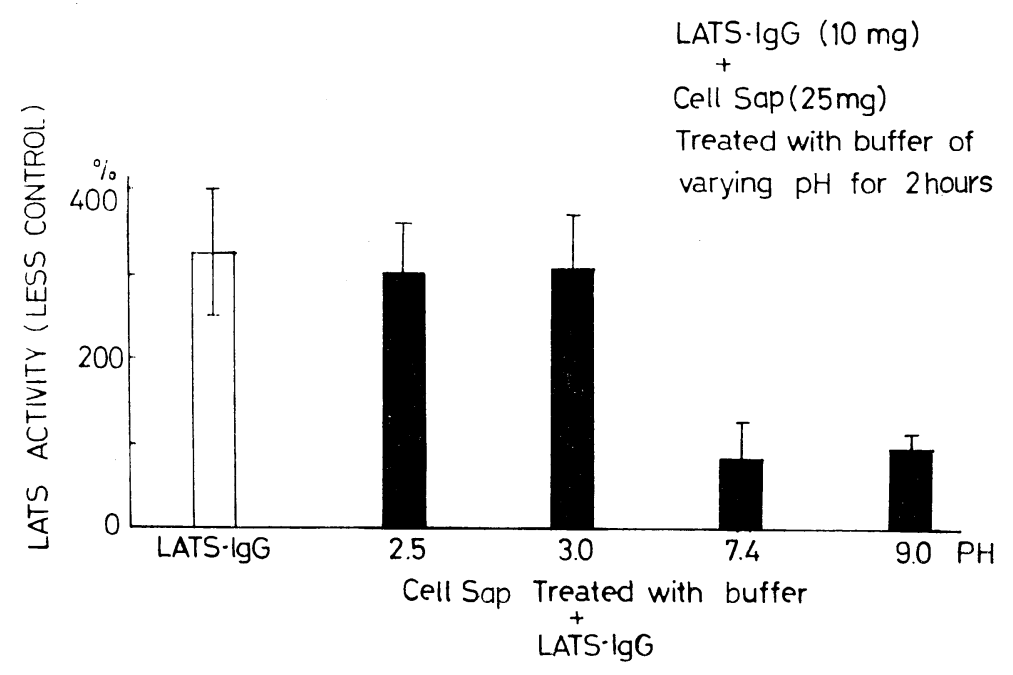

Fig. 11. Effect of treatment with NaSGN and UREA on LATS-neutralizing activity of thyroid cell Sap

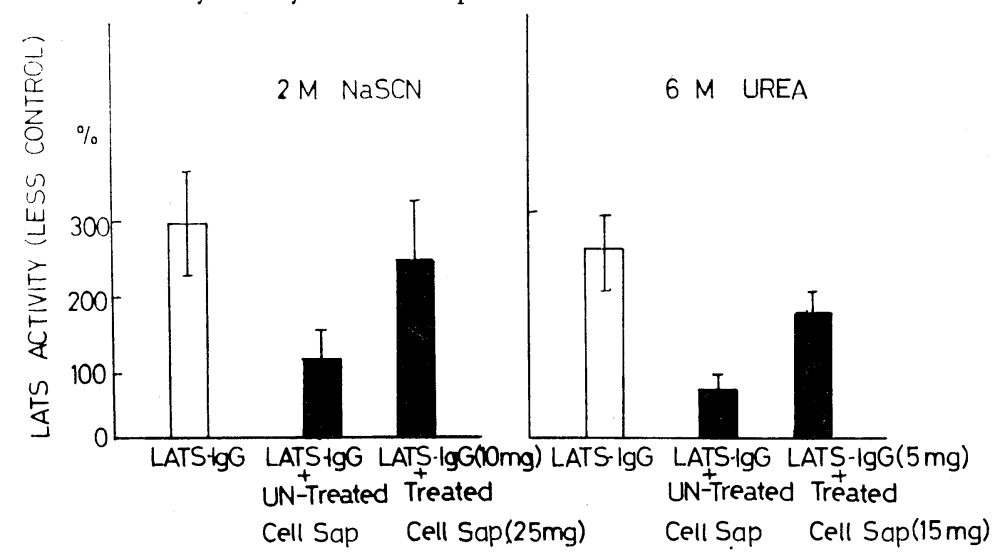

第 45 巻 第 10 号 
同様 LATS 活性を抑制したが， $\mathrm{pH} 2.5$ あるいは $3.0 て ゙$ 前処理するとLATS を抑制しなかつた。同様な方 法で, cell sap $2 \mathrm{M} \mathrm{NaSCN}$ あるいは $6 \mathrm{M}$ urea で処理した後では, LATS 中和能が減弱した。(Fig. 11).

5 ）甲状腺 cell sap 中の LATS 中和物質を分離する目的で以下の実験を行なつた.

まず cell sap 尼 Sepharose 4B で gel filtration するとFig.12のような elution pattern が得られたの で, 各分画を negative pressure dialysis で濃縮, 次いで涷結乾燥し, 一定量づつを LATS-IgG に添加, incubate 後.LATS 活性を測定した。その結果はFig. 13亿示す如く, 各分画共略々同程度の LATS 中和能 を示した. ての成績は sucrose gradient を用いた Beal の報告 ${ }^{14)}$ と軌を一にするものである.

一一方，イオン交換カラムクロマトグラフィーによる分離を行なうため, cell sap を DEAE-G column に

Fig. 12. Fractionation of thyroid cell sap by gel filtration

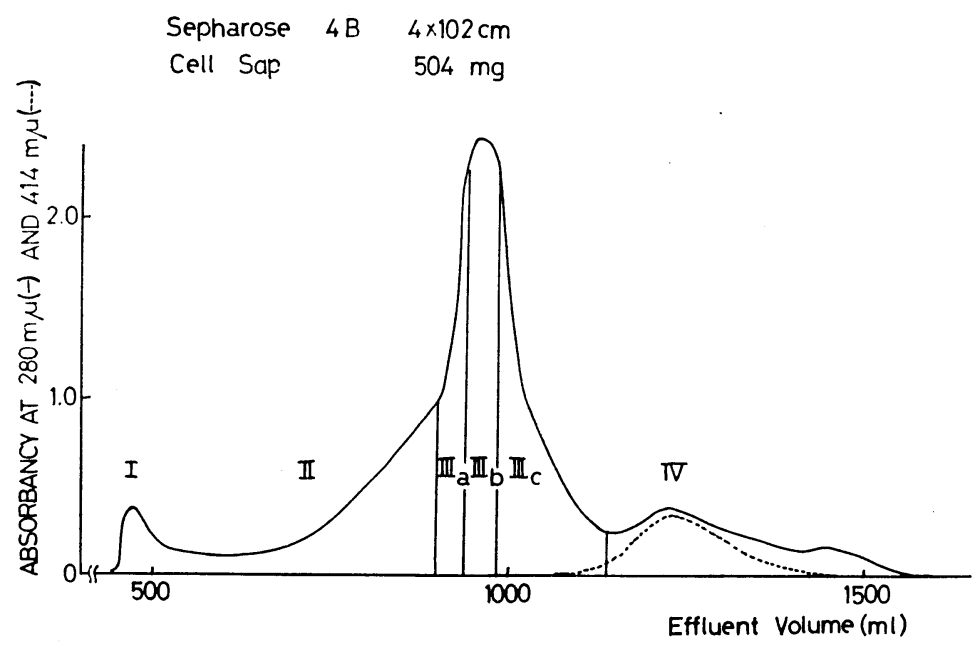

Fig. 13. Neutralization of LATS activity by thyroid cell sap fractionated with Sepharose 4B

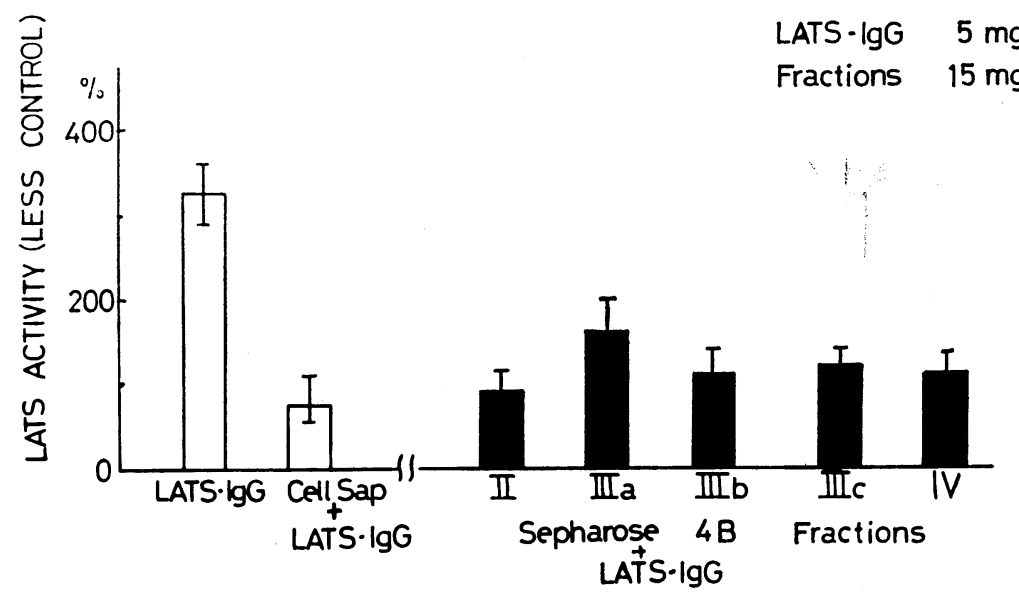


apphyし，Fig. 14亿示すような条件で stepwise にイオン強度をあげて溶出した．得られた分画を濃縮，凍 結乾燥後, LATS-IgG と incubate し assay した所, Fig. 15 亿示すように, 高いイオン強度で溶出された 分画において LATS 中和能が大であり, Fraction VI では蛋白量当中和能は少なくとも 3 倍以上と推定さ れたが, gel filtration, polyacrylamide gel electrophoresis でなお不均一であるため更に分離精製し得る ものと思われる。

\section{LATS と他の抗甲状腺抗体との関係}

以上の成績は，LATS が甲状腺組織成分に対する抗体である可能性を示唆するものであるが，ててで従来 から知られている各種抗甲状腺抗体との関係が問題となる。

1965年 Liddle ${ }^{15}$ ) は，眼球突出，甲状腺腫を伴ない，LATS 陽性で， T 3 suppression test に反応しないが，

Fig. 14. Fraction of thyroid cell Sap by DEAE-cellulose column chromatography

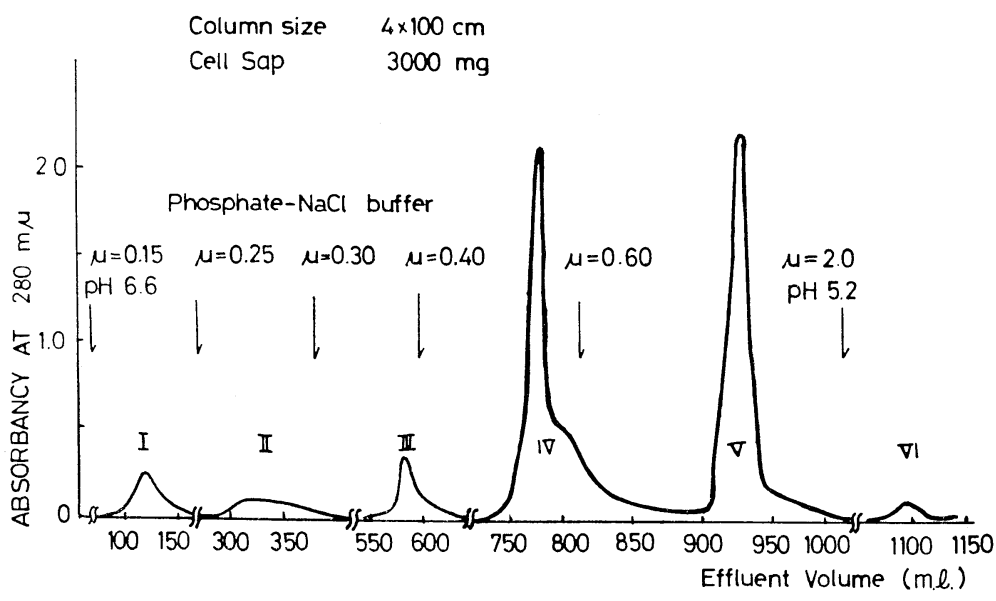

Fig. 15. Neutralization of LATS activity by thyroid cell sap fractionated with DEAE-C column chromatography

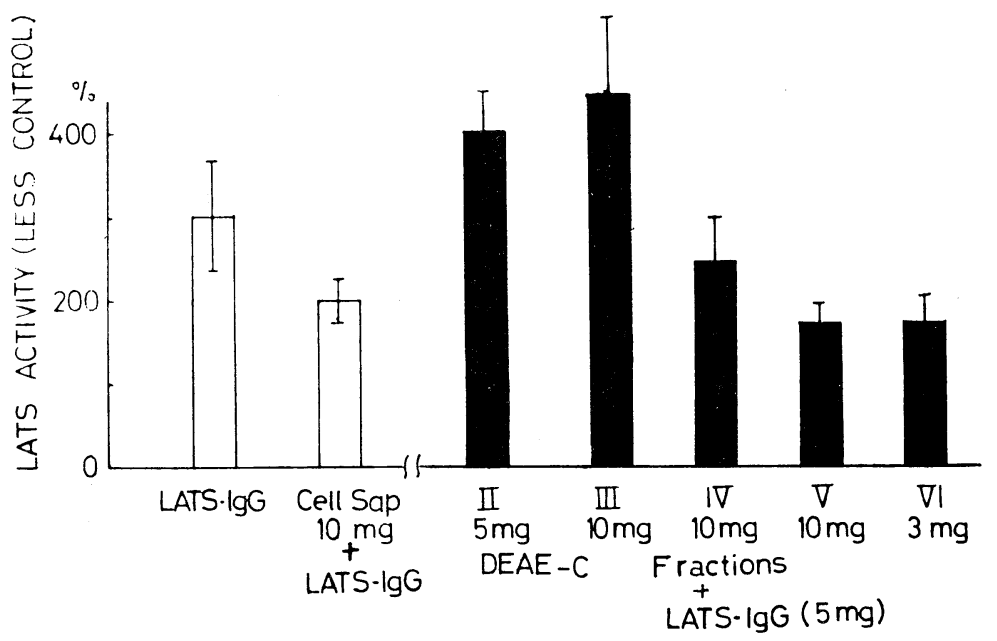


euthyroid である症例を “Graves’ disease without hyperthyroidism”として記載したが，その後類似の

Table 1. Graves' disease without hyperthyroidism

\section{Case : Y.S. $40 \mathrm{M}$}

Exophthalmometry $\left\{\begin{array}{lll}\mathrm{R} & 15 \mathrm{~mm} \\ \mathrm{~L} & 13\end{array}\right.$

Goitre II

BMR $+18 \%$

PBI $8.2 \mu \mathrm{g} / \mathrm{dl}$

${ }^{131} \mathrm{I}_{-} \mathrm{T}_{3} \mathrm{RSU} \quad 28 \%$

${ }^{131}$ I-uptake $\quad 47.8 \%$

Conversion ratio $21.5 \%$

E.H.L. $\quad 4.3$ days

$\mathrm{T}_{3}$-suppression test no response

TSH test no response

LATS (Concentrated lgG) (+)

TRG $2^{12}$

Histological fudings of thyroid : chronic thyroiditis
症例について抗甲状腺抗体の検出, 甲状腺の橋本 病様変化 ${ }^{16)}$ が報告された. 我々も Table 1 亿示す ように類似の症例を経験しているが，てれはバセ ドウ病と橋本病の中間的なものとして, LATS と 他の抗甲状腺抗体との密接な関連を予想させるも のである.

しかしながら，一般のバセドウ病や橋本病にお いて, TRG による抗 thyroglobulin 抗体, GF や cytotoxic factor による抗 microsome 抗体価 と LATS 活性との間には相関を認めることが出 来なかつたので, LATS と抗甲状腺抗体とは関連 があるにしてもその本体は別個のものであろうと 推測される.

5. LATS の adenyl cyclase activity に及ぼす影 響

LATS の甲状腺刺激作用については, in vivo でも in vitroでも種々な指標を用いて研究がす すめられている。とのうち LATS の作用機序を 追求する上に興味あるのは，TSH 始め種々なホ

ルモン作用発現の際の mediotor と目されている cyclic, 3,'5'-AMP が，LATS 作用にも関与している可能

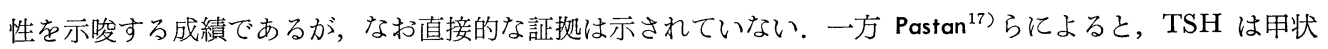
腺 homogenate 中の adenyl cyclase activity を高かめ, ATP から cyclic 3',5'-AMP の生成を促進する と報告している。そてで我々は，彼等の方法に準じ，LATSの adenyl cyclase activity に及ぼす影響に つき検討した．その結果はFig. 16に示す如く，てのような条件下では影響を認めることが出来なかつたが， 今後更に詳細な検討が必要であろう。

Fig. 16. Effect of LATS on the accumulation of cyclic $3^{\prime} 5^{\prime}$-AMP in human thyroid homogenates

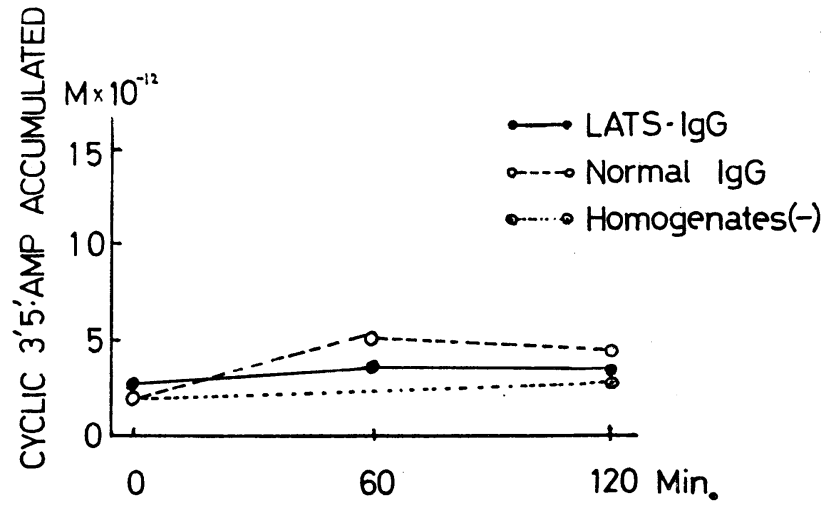




\section{IV 結 語}

以上，甲状腺機能六進症の大部分を占めるバセドウ病において，その病因に密接な関連を有すると思われ る TSH, LATS につき我々の実験成績を述べた。すすなち本症においては，TSH の過剩分泌はみられず 且つ feed back relation は保たれているとと，一方 LATS は，免疫グロブリン IgG と associate し且つ リンパ球培養で産生されるととから一種の抗体と考光られるとと, およびその抗原検索の一環として行なつ た甲状腺内 LATS 中和活性に関する成績などを示した。しかし TSH ゃLATS が本症の病因に直接関与 しているか不かはなお明らかにされておらず, 更に今後の研究の進展に期待したい.

謝 辞

本シンポジゥムの機会を与えられた七条小次郎会長，三宅儀座長，御指導を賜わつた阿部裕教授，熊原雄 一助教授及び研究協力者の方々飞梁謝します.

研究協力者

阪大第一内科 檃岐和之, 岡田義昭, 木村和文, 伊藤貴志男, 小川定男, 井上 雅, 松岡 徹, 橋本琢磨, 大西利夫

第二外科 高井新一郎

婦 人科谷沢修

中 検 新井加余子

大阪市立大学病理 嶋崎昌義

大阪府立成人病センター 森陽一

文献

1) LAMBERG, B.- A., J. RIPATTI, A. GORDIN, H. JUUSTILA, A. SIVULA and G. AF. BJÖRKESTEN. : Acta Endocr. 60 : 157, (1969). $\quad$ 2) GAVALIERI, R.R. : J. Glin. Endocr. 21 : 1455, (1961). $\quad 3$ 3) LEMARGHAND-BERAUD, T., M.R. ASSAYAH, and A. VANNOTTI : Acta Endocr. 45 : 99, (1964). 4 4) DOBYNS, B.M. and S.L. STEELMAN : Endocrinology, $52: 705$, (1953). $\quad 5)$ KUMAHARA, Y., H. IWATSUBO, K. MIYAI, H. MASUI, M. FUKUCHI and H. ABE : J. Clin. Endocr., $27: 333$, (1967). $\quad 6)$ ODELL, W.D., J.F. WILBER and R.D. UTIGER : Recent Progr. Hormone Res. 23 : 47, (1967). 17 ) NATIONAL PITUITARY AGENGY : Personal communication. OKA, T. INOUE and Y. KUMAHARA. in press.

8) FUKUGHI, M., K. MIYAI, T. MATUProc. Univ., Otago Med. School, 34 : 11, (1956). 9) ADAMS, D.D. and H.D. PURVES : J.R. GHIEN : J. Clin. Endocr. 24 : 1005, (1964). 10) KRISS, J.P., V. PLESHAKOV and Glin. Endocr. $26: 504$, (1966).

11) MIYAI, K. and S.C. WERNER : J. ABE : J. Clin. Endocr. $27: 855$, (1967). 12) MIYAI, K., M. FUKUCHI, Y. KUMAHARA and H. Invest. $45: 552$, (1966).

13) BEALL, G. and D.H. SOLOMON : J. Clin. J. Lab. Glin. Med. $73: 988$ (1969). 14) BEALL, G.D DONIAGH, I. ROITT and D. EL. KABIR : J.M. : Amer. J. Med. 39 : 845, (1965).

15) LIDDLE, G.W., R.M. HEYSSEL and McKENZIE, NER, D.A. SCHOLZ and T.P. KEARNS : J. Clin. Endocr. $28: 1623$, (1968).

I. and R. KATZEN : Bioch. Biophy. Res. Comm., 29 : 792, (1967).

質問：永田 格 宮井先生に(1)我々は甲・ミクロゾームが LATS 或いは TSH 何れる不活化するとと を認めている。しかし, 両者の間には差があり, Dose response line の勾配が TSH 中和の場合はゆるや 
かで，そとに質的差があると思つている。（2「「゙」病下垂体の所謂 “abnormal TSH” はradioimmunoassay 上では如何でしたか. (3) 中和能を持つ物質で, マクロゾーム中のあのと cell sap 中のものとの間に質的差 があるとは考えにくいが?

答：阪大一内 宮井潔 (1) クロゾームで TSH が不活性化されたのは非特異的吸着によるのではなか ろうか. Cell sap ではこのような現象はなかつた。 (2)現在教室福地が中心に検討中であるのでいずれ報告 する。(3)今後の検討にまちたい.

追加：名大第一内科 石突吉持 尾形氏へ臨床的に中毒症状並びに中毒所見を全く認め得ず，慢性甲状 腺炎と診断したもので，厳に甲状腺中毒症を除外した。宮井氏へ吾々も甲状腺組織上全く慢性甲状腺炎像を 示したバセドウ病例については昭和42年内科学会総会に於て報告している.

追 加：京府立医大第二内科 越智 幸男 1) LATS と TSH の反応時間の差異, Mckenzie 法にての 反応は少量の TSH は 2 時間值が 8 時間值より高く, LATS は常に 8 時間值が 2 時間值より高い. しかし 多量の TSY は 8 時間值が 2 時間值より高くなるが，24洔間後にはなお反応が持続していて，LATS は TSH 飞比べて長洔間甲状腺を刺激する，2）各種抗体での中和，LATS-IgG 分画の LATS 活性は Anti IgA 及び Anti-IgM では中和されないが, Anti-IgG では活性は殆んど中和される。また IgG の Fab-及 び Fc-fragment に対する抗体で，その活性が中和される. 更に Anti-Kchain 又はAnti- $\lambda$ chain でその活 性の約 $50 \%$ が夫々中和される。乙れら雨抗体を同時に加えるととにより，活性は殆んど完全に中和可能であ る. 以上の実験から LATS は多分 IgG であろうと推定されるが，monoclonal なものではないと思われ る. 3) LATS の作用, LATS は TSH と同様に in vivo にて甲状腺内の Phospholipid 及び RNAへの $\mathrm{P}^{32}$ の転入を促進する。即ち LATS-IgG $60 \mathrm{mg}$ は $\mathrm{P}^{32}$ 注射 8 洔間後のマウス甲状腺内の単位 RNA 及び単 位 Pnospholipid 当りの放射能の增加を起こす。 また同様の実験方法にて $\mathrm{H}^{3}$-uridine の RNA への転入 をむ LATS はTSH の如く促進する. 4) LATS と $\mathrm{TSH}_{(}$の作用機序の相違，ヒョコへの人及びブタ TSH の作用を検討すると甲状腺刺激作用が認められる。LATS はマウスの甲状腺を刺激するが LATS はヒヨコ の甲状腺を全然刺激しない, LATS-IgG 分画をPapain 及び Pepsin 更にそれに Cysteine を加えた処置 をした場合ではマウスの甲状腺は刺激されるが，ヒヨコの甲状腺は全然刺激されなかつた。この事は LATS は小分子となつてあヒヨコの甲状腺を刺激しないととを示唆する. 5) LATS の抗原について, LATS は抗 体であり，その抗原は甲状腺内にあるとの仮説が多く提示されている．ヒト甲状腺内の各分画の LATS 活 性の中和能は Mitochondria 及び Microsome 分画にあるが，特に Microsome に大である，しかしての Microsome 分画の中和能は LATS 飞特異的でなくて TSH あ中和した。 6) LATS 活性と各種甲状腺抗 体, LATS 活性と間接螢光抗体による甲状腺の. Cytoplasm 及び colloid に対する抗体との関係を検討し たが，特に相関関係はなかつた。また LATS 活性と抗 Thyroglobulin 抗体との間にも何等相関を認めな かつた. LATS 活性が 8 洔閆值で 1000\%以上の非常に高いLATS 活性を示す患者血清の半数は上記の諸抗 体が陰性であり，この血清では血清 IgG の增量をも認めなかつた。7）LATS 活性と TSH 値の比較, 人 TSH の Radioimmunoassay を行ないLATS 活性と比較したが, LATS 活性の非常に高いものは TSH 活性を検出出来なかつた。結語 LATS は TSH の如く甲状腺諸代謝を促進するがLepp の云う如く, LATS は TSH と違つて哺乳動物以外の甲状腺を刺激しないのではなかろうか. LATS は抗体かむしれな い. あし抗体としても monoclonal なあのではなかろう.LATS は TSH と蛋白の単なる結合物でもなか ろう. LATS 活性と各種の明状腺抗体と相関関係はない. LATS の抗原を Microsome と推定する免疫反 応は認められなかつた。 